Utah State University

DigitalCommons@USU

\title{
Growth of Trembling Aspen in Relation to Ground Water and Soil Organic Matter
}

\author{
S.A. Wilde \\ D.T. Pronin
}

Follow this and additional works at: https://digitalcommons.usu.edu/aspen_bib

Part of the Forest Sciences Commons

\section{Recommended Citation}

Wilde, S.A. and Pronin, D.T. 1949. Growth of trembling aspen in relation to ground water and soul organic matter. Soil Science Society of America. 14: 345-347.

This Article is brought to you for free and open access by the Aspen Research at DigitalCommons@USU. It has been accepted for inclusion in Aspen Bibliography by an authorized administrator of DigitalCommons@USU. For more information, please contact

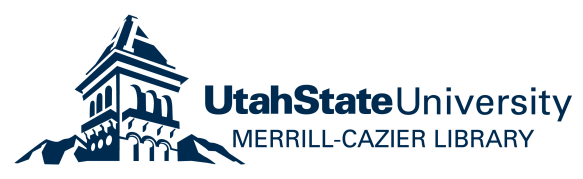




\section{LITERATURE CITED}

1. BJORKMAN. Uber die Bedingungen der Mykorrhizabildung bei Kiefer und Fichte. Symbolae Botanicae Upsaliensis, 6:1-190. 1942 .

2. НАтCH, A. B. The role of mycorrhizae in afforestation. Jour. For., 34:22-29. 1936.

3. The physical basis of mycotrophy in Pinus. Black Rock Forest Bul. 6. 1937.

4. Kitson. R. E., and Mellon, M. G. Colorimetric determination of phosphorus as molybdivanadophosphoric acid. Ind. Eng. Chem., Anal. Ed., 16:379-383. 1944.

5. Kramer, P. J., and Wilbur. K. M. Absorption of radioactive phosphorus by mycorrhizal roots of pine. Science, 110:8-9. 1949.

6. MacDougat, D. T., and Dufrenoy, J. Criteria of nutritive relations of fungi and seed plants in mycorrhizae. Plant Physiol., 21: 1-10. 1946.

7. МсСомв, A. L. Mycorrhizae and phosphorus nutrition of pine seedlings in a prairie soil nursery. Iowa Agr. Exp. Sta. Res. Bul. 314:583-612. 1943.

8. and phosphorus absorption of mycorrhizal and nonmycorrhizal northern white pine and Douglas fir seedlings in relation to fertilizer treatment. Plant Physiol., 21:11-17. 1946.
9. Mitchell, H. L. The growth and nutrition of white pine (Pinus strobus L.) seedlings in cultures with varying nitrogen, phosphorus, potassium, and calcium. Black Rock Forest Bul. 9. 1939.

10. - FinN, R. F., and Rosendahl, R. O. The relation between mycorrhizae and the growth and nutrient absorption of coniferous seedlings in nursery beds. Black Rock Forest Papers, 1:58-73. 1937.

11. Peech, M., and English. L. Rapid microchemical soil tests. Soil Sci, 57:167-195. 1944.

12. ROSENDAHL, R. O. The effect of mycorrhizal and nonmycorrhizal fungi on the availability of difficultly soluble potassium and phosphorus. Soil Sci. Soc. Amer. Proc., $7: 477-479.1943$.

13. Routien, J. B., and Dawson, R. F. Some interrelationships of growth, salt absorption, respiration, and mycorrhizal development in Pinus echinata Mill. Amer. Jour. Bot., 30:440-451. 1943.

14. Stelly, M., and Pierre, W. H. Forms of inorganic phosphorus in the $\mathrm{C}$ horizons of some Iowa soils. Soil Sci. Soc. Amer. Proc., 7:139-147. 1943.

15. White, D. P. Prairie soil as a medium for tree growth. Ecology, 22:298-407. 1941.

\title{
Growth of Trembling Aspen in Relation to Ground Water and Soil Organic Matter ${ }^{1}$
}

\author{
S. A. WILDE and D. T. ProniN ${ }^{2}$
}

$\mathrm{B}$ EFORE the advent of the white man, the poorly drained sandy soils of central Wisconsin supported valuable stands of white pine. During the past 100 years, however, these soils have undergone drastic depletion caused by clear-cut logging, repeated fires, artificial drainage, cultivation, and grazing. By and large, the

TABLE 1.-Comparison of the nomograph values with actual rate of growth of well-stocked stands of trembling aspen as determined on sample plots.

\begin{tabular}{|c|c|c|c|c|c|c|c|c|c|}
\hline $\begin{array}{c}\text { Sample plot } \\
\text { No. }\end{array}$ & $\begin{array}{l}\text { Depth to } \\
\text { ground } \\
\text { water } \\
\text { table } \\
\text { Ins. }\end{array}$ & $\begin{array}{c}\text { Content } \\
\text { of } \\
\text { org. } \\
\text { matter } \\
\% \%\end{array}$ & $\begin{array}{c}\text { Av. age } \\
\text { of stand } \\
\text { Yrs. }\end{array}$ & $\begin{array}{l}\text { Av. } \\
\text { DBH } \\
\text { Ins. }\end{array}$ & $\begin{array}{l}\text { Av. } \\
\text { ht. } \\
\text { Ft. }\end{array}$ & $\begin{array}{c}\text { Av. } \\
\text { annual } \\
\text { ht. } \\
\text { growth } \\
\text { Ins/yr. }\end{array}$ & $\begin{array}{c}\text { Estimated } \\
\text { av. annual } \\
\text { ht. } \\
\text { growth } \\
\text { Ins } / y r .\end{array}$ & $\begin{array}{c}\text { Deviation } \\
\text { of } \\
\text { estimated } \\
\text { values } \\
\text { Ins. }\end{array}$ & $\begin{array}{c}\text { Error } \\
\%\end{array}$ \\
\hline $\begin{array}{l}1 \\
2 \\
3 \\
4 \\
5 \\
6\end{array}$ & $\begin{array}{l}21 \\
20 \\
19 \\
32 \\
52 \\
38 \\
37 \\
20 \\
28 \\
60+ \\
36 \\
48 \\
30 \\
36 \\
16 \\
24 \\
60 \\
24\end{array}$ & $\begin{array}{l}2.8 \\
2.5 \\
3.5 \\
3.6 \\
4.2 \\
3.3 \\
2.7 \\
3.1 \\
1.5 \\
1.7 \\
2.7 \\
3.2 \\
3.7 \\
5.6 \\
2.8 \\
2.7 \\
2.1 \\
3.7\end{array}$ & $\begin{array}{l}20.0 \\
23.2 \\
25.2 \\
27.0 \\
27.8 \\
24.0 \\
27.4 \\
23.8 \\
23.6 \\
40.8 \\
23.2 \\
25.0 \\
27.3 \\
25.6 \\
26.8 \\
24.0 \\
30.3 \\
21.5\end{array}$ & $\begin{array}{l}4.0 \\
4.5 \\
5.3 \\
5.7 \\
5.0 \\
4.6 \\
4.5 \\
3.8 \\
2.6 \\
5.3 \\
4.1 \\
4.8 \\
5.7 \\
5.4 \\
3.2 \\
4.9 \\
5.2 \\
4.6\end{array}$ & $\begin{array}{l}36.6 \\
42.4 \\
46.6 \\
62.6 \\
46.1 \\
38.6 \\
43.6 \\
38.6 \\
31.0 \\
54.4 \\
32.8 \\
46.0 \\
54.6 \\
40.2 \\
32.1 \\
40.8 \\
42.4 \\
38.7\end{array}$ & $\begin{array}{l}21.9 \\
21.9 \\
22.2 \\
24.1 \\
19.9 \\
19.3 \\
19.1 \\
19.5 \\
15.8 \\
13.5 \\
17.0 \\
22.1 \\
24.0 \\
23.5 \\
14.2 \\
20.4 \\
16.0 \\
23.4\end{array}$ & $\begin{array}{l}20.0 \\
19.0 \\
19.0 \\
22.5 \\
19.0 \\
20.5 \\
20.5 \\
20.0 \\
15.0 \\
12.5 \\
21.5 \\
19.5 \\
23.0 \\
22.5 \\
16.0 \\
21.5 \\
16.5 \\
22.0\end{array}$ & $\begin{array}{r}-1.9 \\
-2.9 \\
-3.2 \\
-1.6 \\
-0.9 \\
+1.2 \\
+1.4 \\
+0.5 \\
-0.8 \\
-1.0 \\
+4.5 \\
-2.6 \\
-1.0 \\
-1.0 \\
+1.8 \\
+1.1 \\
+0.5 \\
-1.4\end{array}$ & $\begin{array}{r}8.7 \\
13.2 \\
14.4 \\
6.6 \\
4.5 \\
6.2 \\
7.3 \\
2.6 \\
5.0 \\
7.3 \\
26.5 \\
11.8 \\
4.2 \\
4.3 \\
14.0 \\
5.4 \\
3.0 \\
6.4\end{array}$ \\
\hline
\end{tabular}

${ }^{1}$ Contribution from the Soils Department, University of Wisconsin, Madison, in cooperation with the State Conservation Department and the Nekoosa-Edwards Paper Company. Publication authorized by the director of the Wisconsin Agricultural Experiment Station.

"Professor of Soils and Assistant in Soils, respectively. The writers are indebted to Messrs. F. G. Kilp, R. C. Dosen, E. L. Zicker, R. Wittenkamp, and S. F. Peterson for their help in various phases of field investigations. 


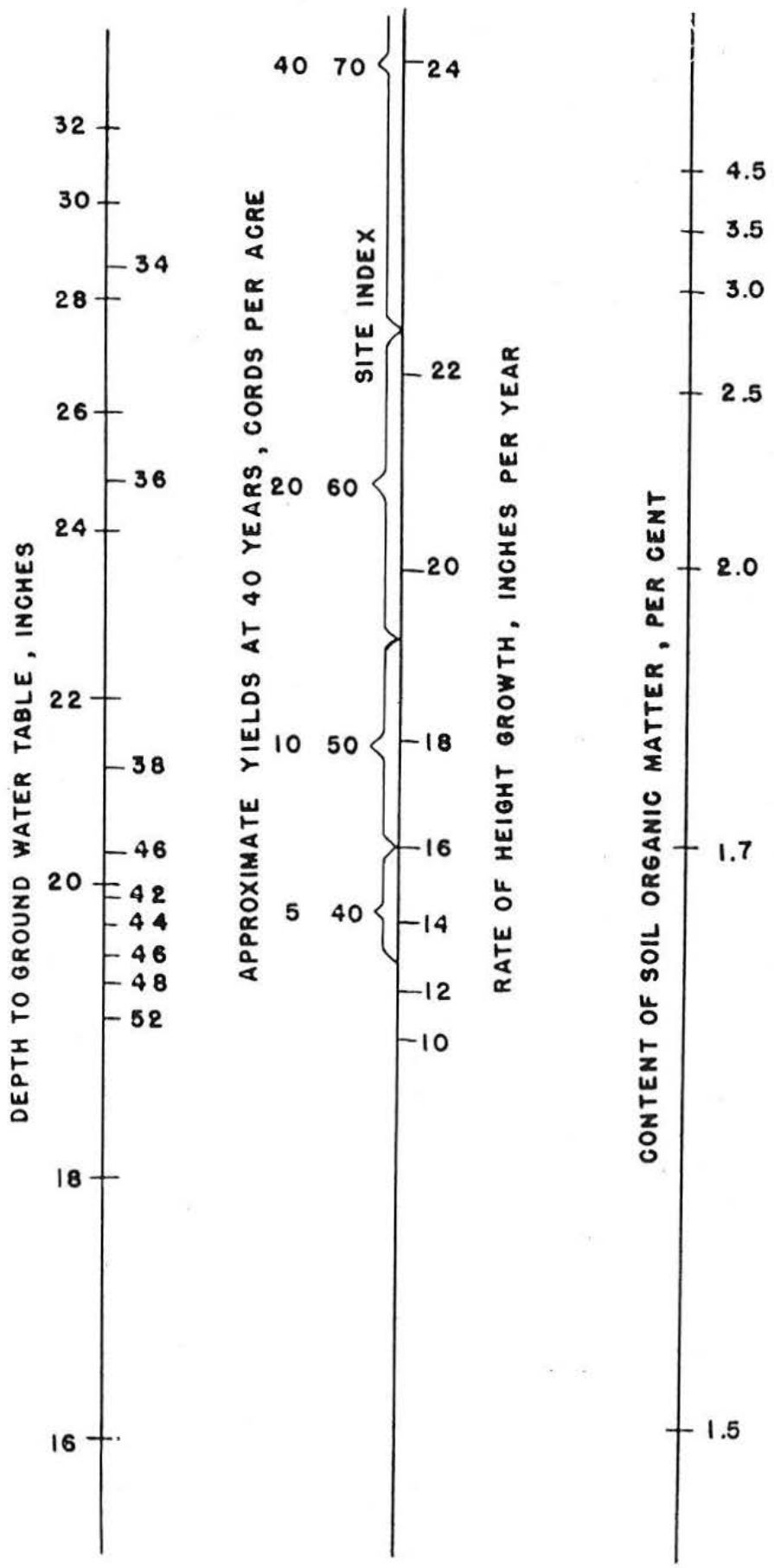

FIG, 1.-Nomograph expressing the relationship between the rate of growth of semimature ( 20 to 27 years) trembling aspen, depth of ground water table (upper limits of gley horizon), and content of soil organic matter (7-inch layer) in quartz sands of central Wisconsin.

soils of this region are derived from highly siliceous material, and adverse influences reduced their nutrient content to mere traces.

Paradoxically, the depletion of soils in central Wisconsin has created substrata of unique ecological interest. The growth of young forest stands on extensive areas of siliceous gley sands is influenced largely by two factors: ground water table and content of soil organic matter. Such conditions provide a rather unusual oppor- tunity to observe the relationship between forest growth and composition of soil unobscured by the co-influence of many factors.

An attempt.to express in concrete figures a correlation between the rate of growth of trembling aspen, content of soil organic matter, and depth to the ground water table was made during the summer of $1947(3,4)$. The rate of growth of trembling aspen was determined on 22 sample plots varying in size from $1 / 5$ to $1 / 2$ of an acre. The age of the aspen stands ranged from 22 to 27 years. The present and the expected yields were determined on the basis of available tables (1). The depth to the upper limits of the deoxidized zone (gley horizon), indicating the prevailing position of the ground water table, was established on each sample plot. Samples were collected from the 7-inch surface layer of soil by means of a sampling tube and were analyzed for their content of organic matter, using a rapid colorimetric procedure (2).

The results obtained are incorporated in the attached nomograph, constructed on a pattern of logarithmic curves by empirical trials. According to this, aspen stands on soils with the ground water table at a depth of 52 inches and an organic matter content of $2.5 \%$ show an average height growth of 18 inches per year; this corresponds to site index 50 and an expected yield of 10 cords per acre at the age of 40 years. On the other hand, aspen stands on soils with the ground water table at a depth of 36 inches and a content of organic matter of $3.5 \%$ show an average height growth of 22 inches per year; this corresponds to site index 60 and an expected yield of fully stocked stands of about 25 cords at the age of 40 years.

In the summer of 1948 the study was repeated on additional 18 one-fifth acre sample plots. The age of aspen stands included in the later survey varied within a somewhat wider range because of the scarcity of well-stocked stands of aspen. The results are presented in Table 1 which compares the actual rate of growth with that predicted on the basis of the nomograph. In 13 out of 18 instances, the error varied between 3.0 and $8.7 \%$, which is a very high degree of accuracy for any type of growth estimate. In four cases, the difference between the estimate and actual height growth ranged from 11.8 to $14.4 \%$; these discrepancies are appreciable, but not unreasonable if one considers the nature of second-growth aspen stands. In one instance, an error as high as $26.5 \%$ was observed, and should be attributed to the influence of factors that have no relation to soil fertility.

It should be stressed that the construction of the nomograph was based largely on the observations of stands underlain by "lean" ground waters having a reaction between $\mathrm{pH} 5.0$ and $\mathrm{pH} 6.5$, specific conductance of 5 to 10 mhos, and total alkalinity not exceeding 20 $\mathrm{ppm}$. A considerably higher rate of growth would be expected if the ground water is enriched in nutrients through contact with lenses of lacustrine clay or other nutrient-bearing substrata ( 5 ).

Aside from the chemical composition of ground water, a number of other factors may be responsible for the discrepancy between the actual and predicted rates 
of stand growth. Among these, origin of the stand (seed or sprout), history of stand development (growthretarding effects of drought and frost), and the nature of soil organic matter (peat vs. litter), should especially be mentioned.

\section{LITERATURE CITED}

I. Gevorkiantz, S. R., and Dufrr. W. A. Methods of predicting growth of forest stands. Lake States For. Exp. Sta. Econ. Notes No. 9. 1938.

2. WILDE, S. A. Rapid colorimetric determination of soil organic matter. Soil Sci. Soc. Amer, Proc. 7:393-394. 1943.
3. - - and ZICKER. E. L. Influence of the ground water table upon the distribution and growth of aspen and jack pine. Techn. Notes No, 30. W is. State Cons. Dept., in coop. with Soils Dept., U.W., Madison. W/is. 1948.

4. - a a a PaUd. B. H. Growth, specific gravity, and chemical composition of quaking aspen on different soil types. U.S. Forest Products Lab. Report SR-12 (Processed). 1948.

5. - and Randall. G. W. Chemical characteristics of ground water in forest and marsh soils of Wisconsin. Proc. of Wis. Acad. Sci., Arts, and Lett. 40 (In print). 1949

\title{
Structure Improvement Following Legume Growth on Unfertilized Subsoil ${ }^{1}$
}

\author{
P. W. Fletcher and R. B. Livingston:
}

$\mathrm{T}$ $\mathrm{HE}$ planting of trees is commonly recommended for the rehabilitation of eroded and abandoned lands which are no longer profitable for agriculture. Frequent planting failures or poor growth on such lands indicate that a preliminary period of site preparation is essential to the success of the tree rotation. Certain legumes may be the best solution to this problem, particularly when the more exacting species of hardwoods are to be planted.

This paper is a progress report of a continuing study, comparing the physical character of an eroded soil profile under Lespedeza sericea Benth. with that of an adjacent bare area.

The iegume was seeded without fertilizer in 1941 by Harris and Drew (2) directly on the $\mathrm{B}$ horizon of a Weldon silt loam (Fig. 1), exposed by road construction equipment in 1939. Despite an initial 95\% mortality, due largely to winter frost heaving, the Lespedeza sericea stand was dense and spreading in 1949 after 8 growing seasons and no intervening attention.

The standing Lespedeza sericea vegetation of 4.33 tons dry weight per acre in August had a rainfall interception capacity of about 0.15 inches. The litter accumulated at the soil surface was equivalent to 7.28 tons dry weight per acre, and had a water-holding capacity of about 0.15 inches.

Soil moisture samples were taken at irregular intervals throughout the summer to a depth of 3 feet on both study plots. During the period from June 20 to July 29, when 5.95 inches of rain fell in 12 showers, soil moisture within the bare area profile remained almost unchanged below the 15 -inch depth, or approximately at field capacity (Fig. 3A). The Lespedeza serica plants

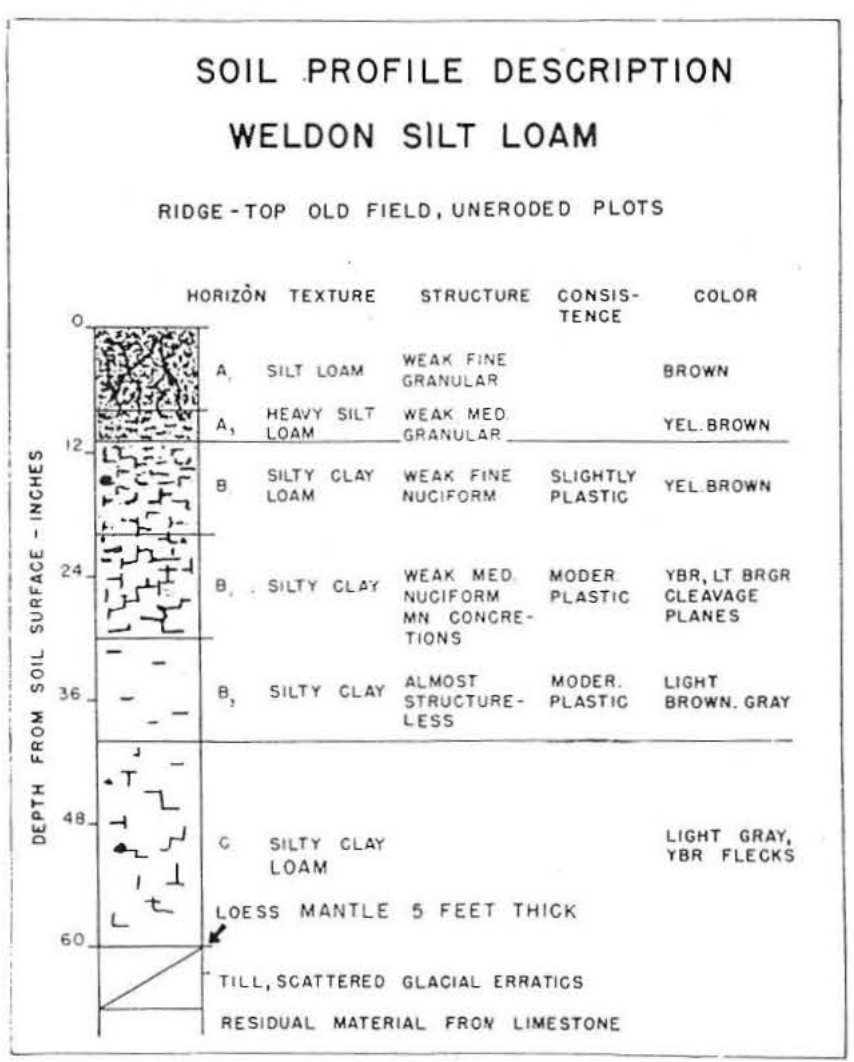

FIG. 1,-The upper 15 inches of this profile were removed arti. ficially, exposing the $B_{1}$ horizon as the surface of the study plots.

(Fig. 2), however, definitely depleted soil moisture to a depth of 3 feet (Fig. 3B), due to the combined effects

\footnotetext{
${ }^{1}$ Contribution from the Department of Soils, Missouri Agricultural Experiment Station, Columbia, Mo. Journal Series No. 1190.

= Instructor, Forestry Department, and Assistant Professor, Botany Department, the senior author on leave from the U. S. Forest Service for graduate study in soils.

"Figures in parentheses refer to "Literature Cited", p. 350.
} 